\title{
AUDIOGRAM PADA PASIEN OMSK DI POLIKLINIK THT RSUP SANGLAH PADA TAHUN 2011-2012
}

\author{
${ }^{1}$ Made Monica Yusilina Mutiara, ${ }^{2} d r$. Sari Wulan Dwi Sutanegara, Sp.THT-KL \\ ${ }^{2}$ dr. I Wayan Sucipta, Sp.THT-KL \\ ${ }^{1}$ Program Studi Pendidikan Dokter, Fakultas Kedokteran Universitas Udayana \\ ${ }^{2}$ Bagian/SMF IImu Kesehatan Telinga Hidung Tenggorokan Fakultas Kedokteran Universitas Udayana / \\ Rumah Sakit Umum Pusat Sanglah, Denpasar \\ myusilina@yahoo.com
}

\begin{abstract}
ABSTRAK
Otitis media supuratif kronik (OMSK) merupakan infeksi kronik di telinga tengah yang dapat mengganggu fungsi pendengaran. Gangguan fungsi pendengaran yang dapat disebabkan oleh OMSK antara lain ketulian, telinga berdenging (tinitus), rasa nyeri di dalam telinga (otalgia), dan keluarnya cairan dari telinga (ottorhea). Adapun pemeriksaan yang dapat dikerjakan untuk menguji fungsi pendengaran salah satunya adalah pemeriksaan audiometri. Pemeriksaan audiometri merupakan pemeriksaan yang bertujuan untuk mengetahui derajat dan jenis ketulian. Pemeriksaan dilakukan dengan menggunakan alat audiometer. Tujuan dari penelitian ini adalah mengetahui tipe-tipe dari ketulian dan derajat ketulian pada penderita OMSK di Poliklinik THT RSUP Sanglah. Metode penelitian yang digunakan adalah metode deskriptif menggunakan rancangan cross sectional, dengan data diambil secara retrospektif dari Poliklinik THT RSUP Sanglah Denpasar. Hasil penelitian menunjukkan bahwa tipe tuli konduktif merupakan tipe gangguan pendengaran yang paling tinggi dengan angka kejadiannya $73,7 \%$. Dari 28 penderita OMSK dengan tuli konduktif, 20 orang memiliki derajat ketulian sedang $(71,4 \%)$.
\end{abstract}

Kata kunci : OMSK, Audiogram, Audiometri

\section{AUDIOGRAM IN ADULT PATIENTS OF CHRONIC SUPPURATIVE OTITIS MEDIA IN DEPARTMENT OF ENT SANGLAH GENERAL HOSPITAL DENPASAR ON THE PERIODE 2011-2012}

\section{ABSTRACT}

Chronic Suppurative Otitis Media (CSOM) is a chronic infection in the middle ear that can disturb the function of hearing. Impaired the function of hearing which can be caused by CSOM is deafness, ears ringing (tinnitus), pain in the ears (otalgia) and discharge from ears (ottorhea). The examination that workable to test the function of hearing is audiometry examination. Audiometry examination is examination which aims to know degress of deafness and kind of deafness. Examination conducted using instrument audiometer. The purpose of this research is to know classification from deafness and the degree of deafness in people with CSOM in Department of ENT in RSUP Sanglah. The Method of this research is descriptive method using cross sectional design and retrospective data taken from Department of ENT in RSUP Sanglah denpasar. The result showed that the type of deaf conductive was the highest type hearing impairments (73,7\%). From 28 people who suffering CSOM with deafness conductive, 20 people having moderate deafness degree $(71,4 \%)$.

Keywords : CSOM , audiogram, audiometry 


\section{PENDAHULUAN}

Infeksi merupakan salah satu penyakit yang dapat diderita oleh siapapun. Salah satu penyakitnya bisa otitis media supuratif kronis (OMSK). OMSK ialah infeksi kronik di telinga tengah dengan perforasi membran timpani dan riwayat keluarnya secret dari telinga baik secara terus menerus atau hilang timbul dengan durasi lebih dari 2 bulan. Ini disebabkan oleh bakteri, fungi dan virus yang mengakibatkan peradangan pada lapisan mukosa. OMSK didalam masyarakat dikenal dengan istilah congek. Penyakit ini umunya bisa mengenai semua umur tapi kebanyakan mengenai anak-anak dengan sosial ekonomi yang rendah.

OMSK sering ditemukan pada negara maju dan berkembang sekitar 1-46\% di setiap komunitas. Dari hasil "WHO Multi Center study" pada tahun 1998 Indonesia termasuk 4 negara di Asia Tenggara dengan prevalensi ketulian yang cukup tinggi (4,6\%), 3 negara lainnya adalah Sri Lanka (8,8\%), Myanmar $(8,4) \%$ dan India $(6,3) \%$. OMSK dilaporkan penyebab terbanyak morbiditas telinga tengah $(3,0 \%)$ yang tipe jinak. OMSK memiliki dampak sosial juga dikalangan masyarakat ini dikarenakan pasien mengalami kehilangan fungsi pendengaran dan dapat berdampak buruk pada perkembangan anak-anak.

Kebanyakan penderita OMSK menganggap penyakit ini merupakan penyakit yang biasa yang nantinya akan sembuh sendiri.

Salah satu komplikasi dari OMSK adalah terjadinya gangguan pendengaran.

Jenis dan derajat gangguan pendengaran yang terjadi pada OMSK dapat bervariasi antara tuli konduktif, tuli campuran dan tuli sensorineural dengan derajat ringan hingga berat. Pada OMSK bentuk paling umum ditemukan adalah tuli konduktif, namun tidak menutup kemungkinan tuli sensorineural dan tuli campuran dapat terjadi. Untuk memeriksa pendengaran diperlukan pemeriksaan bunyi melalui hantaran udara dan hantaran tulang. Tes ini dapat memakai garputala atau audiometer nada murni. Namun hasil dari pemeriksaan garputala hanya dapat menunjukkan jenis ketulian, sedangkan pemeriksaan dengan audiometer akan memberikan jenis dan derajat ketulian.

Tujuan dari penelitian ini adalah untuk mengetahui hasil pemeriksaan audiometri pada penderita OMSK di Poliklinik THT RSUP Sanglah dan juga untuk mengetahui tipe-tipe dari ketulian dan derajat ketulian pada penderita OMSK di Poliklinik THT RSUP sanglah

\section{METODE}

Penelitian ini dilakukan di Poliklinik THT RSUP Sanglah Denpasar pada bulan November 2013 selama kurun waktu 2 minggu. Penelitian ini merupakan penelitian deskriptif yang menggunakan rancangan cross sectional, dengan data diambil secara retrospektif dari Poliklinik THT di RSUP Sanglah Denpasar. Data yang digunakan disini berupa data sekunder. Dimana data sekunder adalah data yang didapat dari rekam medis pasien di RSUP Sanglah Denpasar. Populasi pada penelitian ini adalah penderita OMSK yang datang berobat dan melakukan pemeriksaan audiometri di Poliklinik THT RSUP Sanglah Denpasar dari tahun 2011 hingga tahun 2012. Sampel penelitian adalah seluruh penderita OMSK yang melakukan pemeriksaan audiometri di Poliklinik THT RSUP Sanglah Denpasar dari tahun 2011 hingga tahun 2012 yang memenuhi kriteria inklusi dan eksklusi.

Variabel dalampenelitian ini adalah jenis ketulian dan derajat ketulian. Dimana jenis ketulian ini dibagi atas tuli konduktif, tuli sensorineural, dan tuli campuran. Pada tuli koduktif terdapat gangguan hantaran udara, disebabkan oleh kelainan atau sumbatan di telinga luar atau di telinga tengah. Tuli sensorineural adalah ketidakmampuan fungsi pendengaran karena kerusakan telinga dalam, pada tuli ini terdapat gangguan pada hantaran tulang. Tuli campuran disebabkan oleh kombinasi tuli konduktif dan sensorineural. Menurut ISO derajat ketulian dibagi menjadi: 
Tabel 1. Derajat Ketulian menurut ISO

\begin{tabular}{ll}
\hline $\begin{array}{l}\text { Intensitas } \\
\text { Bunyi }(\mathrm{dB})\end{array}$ & Klasifikasi \\
\hline $0-25 \mathrm{~dB}$ & Normal \\
$26-40 \mathrm{~dB}$ & Tuli ringan \\
$41-60 \mathrm{~dB}$ & Tuli sedang \\
$61-90 \mathrm{~dB}$ & Tuli berat \\
$>90 \mathrm{~dB}$ & Sangat Berat \\
\hline
\end{tabular}

\section{HASIL DAN PENELITIAN}

Berdasarkan data sekunder yang didapatkan di Poliklinik THT RSUP Sanglah, terdapat 38 pasien OMSK pada tahun 2011-2012. Dimana gangguan pendengaran dapat dibagi atas tuli konduktif , tuli sensorineural, serta tuli campuran. Pada tuli konduktif terdapat gangguan hantaran suara, disebabkan oleh kelainan atau sumbatan di telinga luar atau di teliga tengah. Tuli sensorineural adalah ketidakmampuan fungsi pendengaran karena kerusakan telinga dalam, pada tuli ini terdapat gangguan pada hantaran tulang. Tuli campuran disebabkan oleh kombinasi tuli konduktif dan tuli sensorineural

Tabel 2. Distribusi tipe ketulian penderita OSMK di Poliklinik THT RSUP Sanglah tahun 2011-2012

\begin{tabular}{clcc}
\hline NO & JENIS KETULIAN & JUMLAH & PERSEN \\
\hline 1 & Tuli konduktif & 28 & 73,7 \\
2 & Tuli & - & - \\
& Sensorineural & & \\
3 & Tuli Campuran & 10 & 26,3 \\
& Jumlah & 38 & 100 \\
\hline
\end{tabular}

Tabel 3. Distribusi Penderita OMSK berdasarkan Derajat Tipe Ketulian di Poliklinik THT RSUP Sanglah tahun 2011-2012

\begin{tabular}{ccccc}
\hline NO & DERAJAT & \multicolumn{3}{c}{ JENIS KETULIAN } \\
& KETULIAN & TULI KONDUKTIF & TULI SARAF & TULI CAMPURAN \\
\hline 1 & RINGAN & $8(28,6 \%)$ & - & - \\
2 & SEDANG & $20(71,4 \%)$ & - & $3(30 \%)$ \\
3 & BERAT & - & - & $4(40 \%)$ \\
4 & SANGAT BERAT & - & - & $3(30 \%)$ \\
& JUMLAH & $28(100 \%)$ & - & $10(100 \%)$ \\
\hline
\end{tabular}

\section{PEMBAHASAN}

Dari tabel 1 menunjukan bahwa 73,7\% dari penderita OMSK di Poliklinik THT RSUP Sanglah memiliki tipe ketulian yaitu tuli konduktif. Diikuti dengan $26,3 \%$ tipe tuli campuran.

Hasil penelitian ini sesuai dengan penelitian sebelumnya yang menunjukkan bahwa lebih dari 50\% penderita OMSK menderita tuli konduktif. Hal ini disebabkan karena terjadinya perforasi pada gendang telinga dan osikular telinga tengah mengalami gangguan yang diakibatkan oleh osteomielitis. Hal ini juga sesuai dengan penelitian Mohammed Shafiqul Islam et al (2010) menyatakan bahwa sebagian pasien yang menderita OMSK mengalami tuli konduktif $(80,8 \%)$ dari jumlah total 198 pasien.
Dari tabel 2 dapat dilihat bahwa tuli konduktif sebagian besar dengan derajat ketulian sedang $71,4 \%$ dikuti dengan derajat ketulian ringan sebesar 28,6\%, ini menggambarkan masih kurangnya kesadaran masyarakat utuk berobat lebih awal akan kesehatan. Dan juga diikuti dengan tipe tuli campuran dengan derajat ketulian sedang sebesar 30\%, derajat ketulian berat $40 \%$ dan derajat ketulian sangat berat sebesar $30 \%$. Tuli konduktif dengan derajat ketulian sedang memiliki angka kejadian yang paling banyak.

Hal ini sesuai dengan data WHO yang menyatakan bahwa di India anak-anak dengan tuli pada OMSK 94\% adalah dengan derajat ketulian sedang dan sisanya derajat ketulian berat. 


\section{SIMPULAN}

Pada penelitian yang telah dilakukan di Poliklinik THT RSUP Sanglah Denpasar pada tahun 2011 - 2012 terdapat 38 pasien OMSK. Berdasarkan penelitian ini didapatkan bahwa tuli konduktif merupakan tipe gangguan pendengaran yang paling tinggi angka kejadiannya yaitu $73,7 \%$. Dimana ini berarti lebih dari 50\% penderita OMSK di Poliklinik THT RSUP Sanglah menderita tuli konduktif. Sedangkan dilihat dari derajat ketuliannya, pada tuli konduktif sebagian besar memiliki derajat ketulian sedang yaitu $71,4 \%$.

\section{DAFTAR PUSTAKA}

1. Acuin J, Berman S, Morris P, and Hasselt PV. Burden of Illness and Management Options. World Health Organization.2004 : 9-28

2. Bridget Farham. Chronic Suppurative Otitis Media. [serial online] [diakses 22 November 2013]. Diunduh dari URL: http://www.cmej.org.za/index.php/cmej/art icle/view/2464/2540

3. David Parry. Chronic Suppurative Otitis Media. [serial online].[diakses 22 November 2013] diunduh dari URL: http://emedicine.medscape.com/article/859 501-overview

4. Islam Shafiqul M, Islam Rafiqul, Bhuiyan Rahman Ashequr M, Rashid Shazibur, Datta Gopal Pran. Pattern and Degree of Hearing Loss in Chronic Suppurative Otitis Media. Bangladesh J Otorhinolaryngol. 2010; 16(2): $\underline{96-105}$
5. Johnson Marni L. UNDERSTANDING AN AUDIOGRAM. University of South Dakota. 2009:1-2

6. Kenny Tim. Audiometry (hearing test). [serial online] [diakses 22 November 2013] diunduh dari

URL:

http://www.patient.co.uk/health/Audiometr $\mathrm{y}$-(Hearing-Tests).htm.

7. Mahr Allen. Audiogram and What They Tell Us About Hearing Loss. [serial online] [diakses 22 November 2013]. Diunduh dari: URL:

http://www.pacificaudiology.com/audigram /uya.html.

8. Meneesh R. Juvekar. Ear - Complications of Chronic Suppurative Otitis Media. [serial online].[diakses 22 November 2013] Diunduh dari URL: http://specialistent.com/ear/complications-chronicsuppurative-otitis-media.aspx

9. Mohsin Mohd. Abdul, Kumar R Mahendra. Sensory Neural Hearing loss In Chronic Suppurative Otitis Media of Tubotympanic Variety. National Journal of Otorhinolaryngology and Head \& Neck Surgery.2013: Vol. 1 (10)

10. Peter S. Morris, Amanda J. Leach. Acute and Chronic Otitis Media. Pediatr Clin N Am. 2009; 56 : 1383-99

11. Sutirto Indro, Hendarmin Hendarto $H$. Audiologi. Dalam: Nurbaiti Iskandar, Efiaty Arsyad Soepardi. Buku Ajar Ilmu Penyakit Telinga Hidung Tenggorokan. 1990. FK UI Jakarta. 1991;h.24-38 